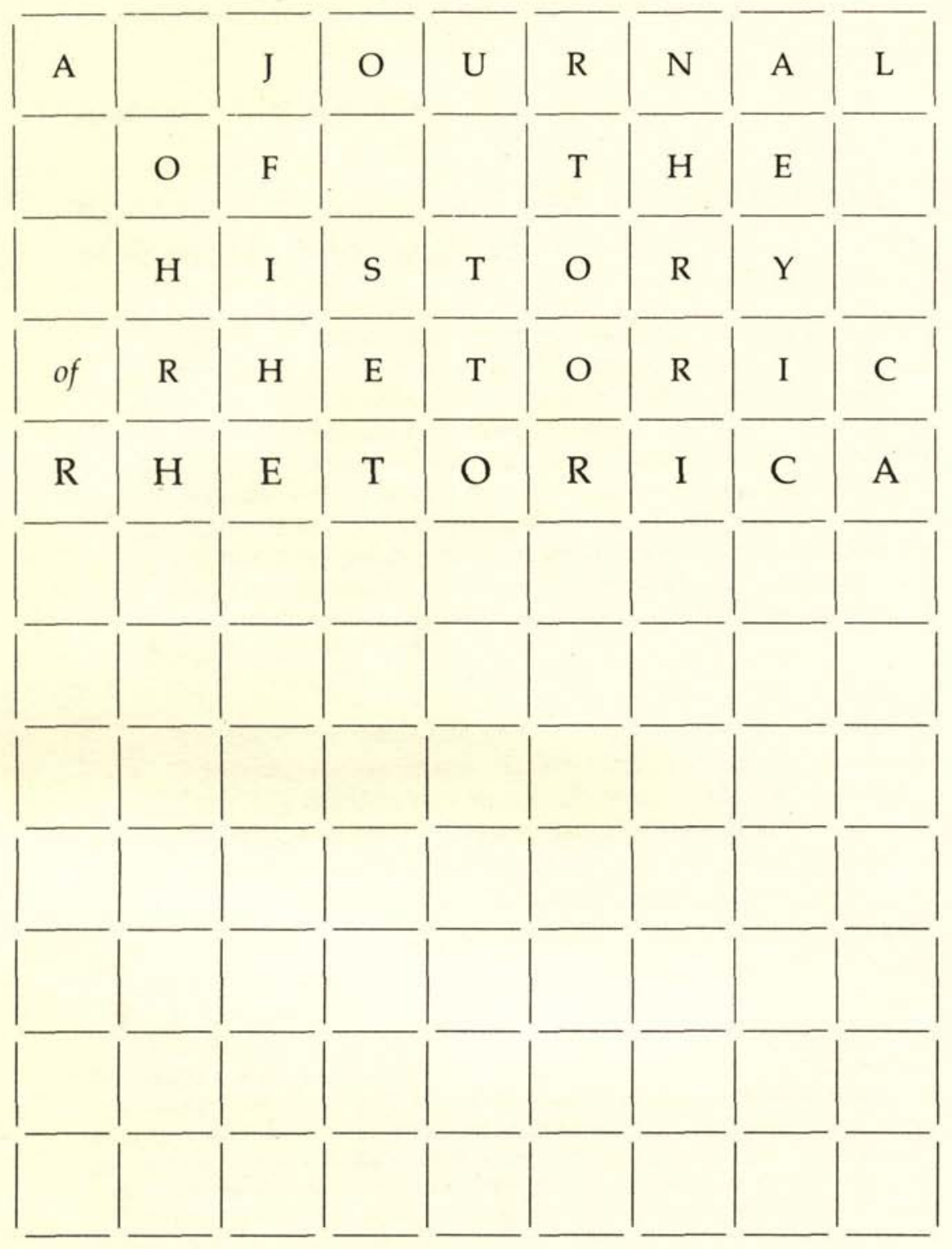




\title{
Rhetoric, Dialectic, and Literature in the Work of Francisco Sánchez, El Brocense
}

\begin{abstract}
Francisco Sánchez wrote two rhetorical treatises to facilitate the interpretation of the work of poets and orators: De arte dicendi (1556) and Organum dialecticum et rhetoricum (1579). In $1556 \mathrm{El}$ Brocense adhered to the classical categories of rhetoric, but in 1579 he adopted the division proposed by Peter Ramus: that is, he assigned inventio and dispositio to dialectic and elocutio and pronuntiatio to rhetoric. In De arte dicendi as well as in Organum dialecticum et rhetoricum, El Brocense demonstrated the validity of the rules of inventio and dispositio in the composition and interpretation of literary works. His treatises thus show the influence of rhetoric and dialectic on the interpretation of classical literature in his day.
\end{abstract}

T hrough the rhetorical and dialectical treatises of Francisco

$\mathrm{T}$ Sánchez de las Brozas, El Brocense, ${ }^{1}$ it is possible to examine the relationship among rhetoric, dialectic, and literature in the Renaissance. As examples of humanist scholarship in the second half of the sixteenth century, the rhetorical treatises of El Brocense, as well as many of his other works, reflect his remarkable critical insight and clearly establish the influence of rhetoric

\footnotetext{
${ }^{1}$ Francisco Sánchez de las Brozas, primarily known for his grammatical text Minerva seu de linguae Latinae causis et elegantia (1562), lived between 1523 and 1600 and was a professor of rhetoric, Greek, and Latin at the University of Salamanca. El Brocense took an interest in a wide variety of subjects and studied classical philology, theology, music, rhetoric, poetry, architecture, archaeology, cosmography, astronomy, medicine, law, and philosophy. His complete works, edited by Gregorio Mayáns, bring together twenty-seven of his treatises. (See G. Mayáns, Francisci Sanctii Brocensis opera omnia [Geneva: Fratres de Tournes, 1766].) On the
}

OThe International Society for the History of Rhetoric, Rhetorica, Volume XIII, Number 1 (Winter, 1995) 
on literature and literary criticism in his day.

In 1556, at the age of thirty-three, Francisco Sánchez published De arte dicendi ${ }^{2}$ at the request of the University of Salamanca, where he was a professor. Twenty-three years later, he published his more mature work, Organum dialecticum et rhetoricum, ${ }^{3}$ which involves a revision of his earlier work as well as a change of perspective. De arte dicendi and Organum dialecticum et rhetoricum have many points in common and some chapters are literally the same. However, they differ substantially in the treatment of the relationship between rhetoric and dialectic.

By the sixteenth century Rudolph Agricola had already proposed that argumentation, traditionally considered a component of

life and works of El Brocense, see U. González de la Calle, Ensayo biográfico. Vida profesional y académica de Francisco Sanchez de las Brozas (Madrid: Imprenta Cervantina, 1922); U. González de la Calle, Francisco Sánchez de las Brozas. Su vida profesional y académica (Madrid: Victoriano Suárez, 1923); A. F. G. Bell, Francisco Sánchez el Brocense (Oxford: Oxford University Press, 1925); J. M. Liaño, Sanctius el Brocense (Madrid: Universidad de Salamanca, 1971); and Marqués de Morante, Biografía del Maestro Francisco Sánchez de las Brozas (Cáceres: Institución Cultural "El Brocense"Diputación Provincial de Cáceres, 1985; rpt. of 1859 ed.).

${ }^{2}$ De arte dicendi liber unus (Salamanca: Andreas a Portonariis, 1556). This work was reissued two years later with significant changes made by the author: De arte dicendi liber unus and De auctoribus interpretandis sive de exercitatione (Salamanca: Mathias Gastius, 1558). This new edition of De arte dicendi was republished in 1569 and in 1573 with minimal changes. For this reason, I have relied on the second, revised edition (1558), which also had the greatest circulation. This work has been reprinted recently in an excellent bilingual, Latin-Spanish edition: F. Sánchez de las Brozas, De arte dicendi, introduction and translation by the editor Eustaquio Sánchez Salor, in F. Sánchez de las Brozas, Obras I. Escritos retóricos (Cáceres: Excma. Diputación Provincial de Cáceres, 1985), pp. 9-159. Further citations refer to this edition.

${ }^{3}$ Organum dialecticum et rhetoricum cunctis disciplinis utilissimum, ac necessarium (Lyons: Antonius Gryphius, 1579). Further citations refer to the bilingual LatinSpanish edition: F. Sánchez de las Brozas, Organum dialecticum et rhetoricum, translation and footnotes by the editor César Chaparro Gómez, in F. Sánchez de las Brozas, Obras I. Escritos retóricos, pp. 161-371. 
rhetorical inventio, should be assigned to dialectic. ${ }^{4}$ This proposal, along with the influence of George of Trebizond's De artificio Ciceronianae orationis, which was published in 1435 and highlights the importance of elocutio with respect to other rhetorical operations, resulted in a reduction of the field of rhetoric. ${ }^{5}$

In 1531 Juan Luis Vives considered the problem of the decline of rhetoric, and upon examining its parts, came to the conclusion that some of them are similar to the parts that make up the other sciences. Going even further than Agricola, he proposed that inventio and dispositio belong to dialectic, thereby reducing rhetoric to elocutio. ${ }^{6}$ By not specifying the important rhetorical role of persuasion, Peter Ramus also assimilated the traditional contents of inventio and dispositio to those of dialectic, so that rhetoric was reduced to elocutio and actio. ${ }^{7}$

This tendency to reduce the parts of rhetoric, which thus comes to be considered a simple discipline of verbal ornamentation, is characteristic of the sixteenth century. Vasile Florescu sees in this reduction a process of "literaturization" of rhetoric, during which it loses its validity as the science of persuasion and is reduced to a simple strategy for literary ornamentation. ${ }^{8}$ The influence of Agricola, Vives, and Ramus would also be felt in Spain, so that $E l$ Brocense was forced to weigh their ideas against those of the classical authors.

Some Spanish humanists followed Juan Luis Vives' lead and proclaimed the supremacy of reason over the systematic adherence to the precepts of antiquity. This was true in the case of $E l$

${ }^{4}$ De inventione dialectica libri omnes et integri et recogniti . . per Alardum Aemstelredamum accuratissime emendati et additis annotationibus illustrati (Cologne: Ioannes Gymnicus, 1539).

5See C. Vasoli, La dialettica e la retorica dell'Umanesimo. "Invenzione" e "metodo" nella cultura del XV e XVI secolo (Milan: Feltrinelli, 1968), pp. 166-82; V. Florescu, La rhétorique et la néorhétorique (Paris-Bucharest: "Les Belles Lettres"-Editura Academiei, 1982), p. 111; and T. Albaladejo, Retórica (Madrid: Síntesis, 1989), p. 35.

${ }^{6}$ Rhetorica sive de recte dicendi ratione libri tres (1536).

${ }^{7}$ Rhetoricae distinctiones in Quintilianum (Paris: Matthaeus David, 1549).

"See La rhétorique et la néorhétorique, p. 107. The French term "littératurisation" appears in this work. In La retorica nel suo sviluppo storico (Bologna: II Mulino, 1971), the Italian term "letteraturizzazione" is used. See G. A. Kennedy, Classical Rhetoric and Its Christian and Secular Tradition from Ancient to Modern Times (Chapel Hill: The University of North Carolina Press, 1980), p. 5. 
Brocense, whose independent thinking resulted in more than a few troublesome disputes and two inquisition trials. El Brocense rejected all that is not definable by reason and encouraged his students not to believe anyone, not even him, unless he was able to defend his assertions with solid reasoning. His support of educational reform at the University of Salamanca would soon come up against the opposition of his colleagues who, nonetheless, recognized his achievement as a scholar as well as a teacher. ${ }^{9}$

There is one essential difference between De arte dicendi, the most important edition of which was published in 1558, and Organum dialecticum et rhetoricum, published in 1579 . In the first work, De arte dicendi, El Brocense adhered to the classical division of the parts of rhetoric. ${ }^{10}$ However, in Organum dialecticum et rhetoricum he finally accepted the distribution of the parts of discourse proposed by Ramus, assigning inventio and dispositio to dialectic and elocutio and pronuntiatio to rhetoric. ${ }^{11}$

At the end of De arte dicendi, El Brocense includes a practical manual entitled De auctoribus interpretandis. In the prologue of De arte dicendi, El Brocense explains that he has composed it to facilitate the understanding of poets and orators, ${ }^{12}$ leaving no doubt about the importance of rhetoric in the analysis of literature. This is reinforced in the manual, where he offers a method of interpretation of

'See L. Merino Jerez, La pedagogía en la retórica del Brocense (Cáceres: Institución cultural "El Brocense"--Diputación Provincial de Cáceres, 1992), pp. 304-8.

${ }^{10}$ Francisco Sánchez divides his treatise into three main parts. He includes memoria under the heading of dispositio and pronuntiatio under elocutio. He claims that his discussion of elocutio adheres to the propositions put forward by Omer Talon. See De arte dicendi, pp. 38-39.

11"Dialecticae partes esse duas: inuentionem et dispositionem.... Rhetoricae partes esse duas: elocutionem et actionem" (Organum dialecticum et rhetoricum, pp. 182-83). Memoria is found at the end of the section on dispositio, and El Brocense relates it to dialectic as Peter Ramus had. See Ramus, Rhetoricae distinctiones in Quintilianum, pp. 30-31. On the influence of Ramus on the work of El Brocense, see L. Merino Jerez, La pedagogía en la retórica del Brocense; and G. Clérico, "Ramisme et post-ramisme: la répartition des 'arts' au XVIe s.," Histoire. Épistémologie. Langage 8,1 (1986): 53-70.

12 "... artem scribere, qua quiuis possit et in poetarum et oratorum scriptis non sine laude diuagari..." (De arte dicendi, p. 36). 
literary texts based on the rhetorical rules presented in the accompanying theoretical treatise. ${ }^{13}$

To achieve his goal, El Brocense sets his own path, sifting through his sources and evolving a kind of method. Without omitting the rhetorical precepts of other authors, he combines the most interesting ideas of Cicero, Quintilian, Hermogenes, and Aristotle, classifying and ranking them in the process. First he discusses inventio, then dispositio, including memoria, which he holds to be of great help to dispositio. At this point, he admits having made a great effort to look for citations from established authors to exemplify his precepts. Finally, he refers to elocutio; here he follows the method of Omer Talon, which he believes to be the most accurate one available, although he warns that he has changed a few things to release himself from the burden of having to follow any master. In this chapter he also includes actio or pronuntiatio. Moreover, he predicts that his work will be considered controversial by those who hold that elocutio belongs to oratory, while inventio and dispositio belong to dialectic.

However, El Brocense asserts his intention to limit himself, for the moment, to ordering the precepts of antiquity and to present his own opinion on the more controversial subject at a later time. ${ }^{14}$

Therefore, in his first rhetorical work El Brocense essentially adheres to classical precepts. He maintains the five traditional parts of rhetoric, although he rearranges them in an original manner. He conceives of rhetoric not only as a useful tool for explaining the components of discourse, but also for interpreting poetry, as indicated by his assertion that his work is principally meant to aid in the understanding of poets and orators. During this period of the Renaissance the term "poet" usually refers to authors of all types of literary texts and, in fact, De arte dicendi provides examples from authors of every literary genre, including lyric, drama, and epic. El Brocense thus proposes his own system of analysis to be applied to the interpretation of any literary genre.

El Brocense firmly believes, and so maintains, that it is more difficult to analyze texts that are already written than it is to write

${ }^{13}$ De auctoribus interpretandis sive de exercitatione, in Mayáns, Opera omnia, 2.7577. See L. Merino Jerez, La pedagogía en la retórica del Brocense, pp. 254-67.

${ }^{14}$ De arte dicendi, pp. $36-39$. 
new ones. ${ }^{15}$ For this reason, in De auctoribus interpretandis he proposes his own method of analysis to facilitate the act of interpretation. This position is original when compared to that of the rest of the prescriptive Spanish critics, who paid as much attention to composition as to analysis of the work. ${ }^{16}$

Peter Ramus had previously proposed a unique and universal system of exercitationis ratio (having to do with the practical side of the different disciplines). Ramus' system consists of two parts: analysis or interpretation of an already-existing text, and genesis or composition of a new one. ${ }^{17} \mathrm{El}$ Brocense bases his method on the Ramist system but holds the interpretation of texts to be more important than their composition. This shows that El Brocense is primarily concerned with developing a method of textual analysis. ${ }^{18}$

First, El Brocense's method of interpretation requires identifying the genre and determining whether or not the text adheres to the rules of rhetoric. This analysis should take into account the entire work in a search for the ultimate meaning which animates it. The importance placed on analyzing the entire work is in keeping

${ }^{15}$ "Maioris esse semper credidi diligentiae aliena scripta retexere quam noua proprio Marte componere" (De auctoribus interpretandis, p. 75).

${ }^{16}$ See A. Martí, La preceptiva retórica española en el Siglo de Oro (Madrid: Gredos, 1972); J. Rico Verdú, La retórica española de los siglos XVI y XVII (Madrid: C.S.I.C., 1973); E. Artaza, El "ars narrandi" en el siglo XVI español (Bilbao: Universidad de Deusto, 1989); L. Merino Jerez, La pedagogía en la retórica del Brocense; A. García Berrio, Formación de la teoria literaria moderna 1. La tópica horacina en Europa (Madrid: Cupsa, 1977); idem, Formación de la teoría literaria moderna 2. Teoría poetica del Siglo de Oro (Murcia: Universidad de Murcia, 1980); L. López Grigera, "Introduction to the Study of Rhetoric in Sixteenth-Century Spain," Dispositio 8 (1983): 22-23; and D. Abbott, "La Retórica y el Renacimiento: An Overview of Spanish Theory," in J. J. Murphy (ed.), Renaissance Eloquence (Berkeley-Los Angeles: University of California Press, 1983), pp. 95-104.

${ }^{17}$ At first, Peter Ramus divided dialectical exercitatio into three parts: interpretatio, on the one hand, and scriptio and dictio, on the other (Dialecticae institutiones [Paris: I. Bogardus, 1543], ff. 42-54). In 1549, Ramus proposed a system that divides exercitatio into two parts: analysis and genesis. Analysis requires carrying out auditio followed by lectio, and genesis calls for scriptio and dictio (Rhetoricae distinctiones in Quintilianum, pp. 97-98). On Ramus' system see L. Merino Jerez, La pedagogía en la retórica del Brocense, pp. 208-18; and K. Meerhoff, Rhétorique et poétique au XVI s. en France (Leiden: Brill, 1986).

${ }^{18}$ As L. Merino Jerez points out, El Brocense provides a novel interpretation of the Ramist model which inspires him by focusing on analysis, which he relates to lectio without reference to auditio. See La pedagogía en la retórica del Brocense, pp. 173, 
with the original textual nature of rhetoric and poetics. Then it is necessary to find the central question or theme and examine the arguments and the loci communes employed. ${ }^{19}$

The devices described so far belong to the realm of inventio. In fact, the question, the arguments, and the topics are the very categories that divide the act of inventio in De arte dicendi, so that the theoretical and the practical are logically related in a coherent fashion. The two final analytical devices discussed, however, come under the realm of dispositio, which El Brocense divides into argumentatio and methodus. Argumentatio includes syllogisms of argumentation. Methodus is concerned with the analysis of the parts of discourse-that is, the exordium, narratio, confirmatio, and peroratio-in order to determine whether the text follows a socalled natural order (methodus doctrinae) or whether it presents modifications (methodus prudentiae). ${ }^{20}$ El Brocense adheres to the conception of methodus implied in the first stages of Ramist thought. $^{21}$ Thus methodus is divided into methodus doctrinae (an expository approach where classifications and definitions proceed from the general to the particular and conclude with examples) and methodus prudentiae (an approach that favors clarity of exposition over the nature of a person, thing, circumstance, or place).22 As in the case of the analytical devices ascribed to inventio, those

254-58. On the method of textual analysis introduced by Agricola and later elaborated by the Ramists, and on which El Brocense bases his own method, see L. Merino Jerez, La pedagogía en la retórica del Brocense, pp. 213-14; K. Meerhoff, Rhétorique et poétique au XVI's. en France, pp. 180-81; idem, "Pédagogie et rhétorique ramistes. Le cas Fouquelin," Rhetorica 5 (1987): 419-30; idem, "Melanchthon lecteur d'Agricola. Rhétorique et analyse textuelle," Reforme, Humanisme, Renaissance 30 (June, 1990): 517; idem, "Logic and Eloquence: A Ramusian Revolution?" Argumentation 5 (1991): 357-74; and idem, "Rhétorique néolatine et culture vernaculaire. Les analyses textuelles de B. Aneau," Études littéraires 24,3 (Winter, 1991-92): 63-85.

${ }^{19}$ De auctoribus interpretandis, pp. 75-76.

${ }^{20}$ De arte dicendi, pp. 80-99.

${ }^{21}$ On Ramus' methodus see L. Merino Jerez, La pedagogía en la retórica del Brocense, pp. 94-116, 139-51. Hereafter, the Ramist doctrine on methodus would evolve. On this evolution, see W. J. Ong, Ramus, Method and the Decay of the Dialogue (Cambridge: Harvard University Press, 1958); C. Vasoli, La dialettica e la retorica dell'Umanesimo; and K. Meerhoff, Rhetorique et poetique au XVI s. en France.

${ }^{22}$ This notion is proposed in Dialectici commentarii libri tres (1546), a work attributed to Omer Talon. Although El Brocense does not adopt the assignation of inventio and dispositio to dialectic in De arte dicendi, his debt to Ramist thought is evident at this stage and is confirmed in Organum dialecticum et rhetoricum. 
that correspond to dispositio adhere to what is presented in De arte dicendi, where one must turn in order to derive the precepts. The aim is to reconstruct the possible alterations in the natural order which the writer has made in order to understand the meaning of the text, which is based on arguments taken from the topics and presented by means of argumentation. ${ }^{23}$

Resorting to inventio and dispositio indicates that the entire apparatus of rhetorical techniques is relevant to the interpretation of literary works. However, this method is incomplete, as it does not pay attention to elocutio in practice. For this reason, $\mathrm{El}$ Brocense's conception of rhetoric at this time does not contribute to the process of "literaturization" described by Florescu. In fact, the analysis of the text is essentially based on inventio and dispositio. In this way, El Brocense's method concentrates precisely on the aspects of literary criticism most neglected by many sixteenth-century writers. Consequently, when De arte dicendi and De auctoribus interpretandis were published in tandem in 1558 , the position embraced by $\mathrm{El} \mathrm{Brocense}$ was not yet aligned with the more prescriptive one of Ramus.

In his rhetorical treatise of 1579, Organum dialecticum et rhetoricum, El Brocense changes his mind significantly. Influenced by the works of Rudolph Agricola, Luis Vives ${ }^{24}$ and, in particular, Peter Ramus, ${ }^{25}$ he revises his initial position. El Brocense agrees with Juan Luis Vives about the role of inventio and dispositio, but, unlike Vives, considers pronuntiatio part of rhetoric. Actually, El Brocense accepts Ramus' position entirely and ascribes inventio and dispositio to dialectic, thereby limiting rhetoric to elocutio and pronuntiatio. ${ }^{26}$

However, the acceptance of Ramus' position does not involve a radical change in the content of the treatise. To be sure, assigning inventio and dispositio to dialectic requires reformulating some sec-

${ }^{23}$ See L. Merino Jerez, La pedagogia en la retorica del Brocense, pp. 254-67.

${ }^{24}$ See U. González de la Calle, Francisco Sánchez de la Brozas. Su vida profesional y académica, pp. 154 ff.; and C. Chaparro Gómez, "Introducción," in Tratado de dialéctica y retórica, in F. Sánchez de las Brozas, Obras I. Escritos retóricos, pp. 163-76.

${ }^{25}$ See L. Merino Jerez, La pedagogía en la retórica del Brocense.

${ }^{26} \mathrm{P}$. Ramus, Rhetoricae distinctiones in Quintilianum, pp. 30-31, and Organum dialecticum et rhetoricum, pp. 182-85. 
tions and introducing logical propositions to allow for the restructuring of the categories. However, the aim of Organum dialecticum et rhetoricum is essentially identical to that of De arte dicendi, and the organization and content of both works are very similar. In both cases $\mathrm{El}$ Brocense provides examples of precepts from poets and orators to show their utility in the interpretation of literary works and speeches. And just as inventio and dispositio are related to literature when they were assigned to rhetoric, the same holds true now when they are assigned to dialectic. We thus find that dialectic, which had not traditionally been associated with literature, turns out to be of great utility in the interpretation of literary works. This is an indication of the close relationship between the different forms of knowledge at this time.

In the dedication to his children that introduces Organum dialecticum et rhetoricum, El Brocense maintains that rhetorical and dialectical precepts had, in effect, never been classified accurately. In his opinion, rhetoricians had transgressed their proper boundaries when they claimed the five traditional rhetorical categories, as well as the realm of judicial oratory and the different types of philosophy. ${ }^{27}$

From the beginning, Francisco Sánchez asserts that dialectic or logic is the device that all other arts employ. Consequently, the study of this discipline should precede all others, with the exception of grammar. In this way, he follows the approach proposed by Vives. ${ }^{28}$ It is necessary to begin with grammar in order to be able to organize the words, followed by dialectic to be able to arrange them rationally, and finally rhetoric to change and adorn the words with figures. Drawing from the precepts of Plato, Aristotle, and Cicero, El Brocense argues that reason is the essential component of dialectic and that it is responsible for discovering the arguments and analyzing or judging them. On these grounds, inventio and dispositio belong exclusively to dialectic, whereas rhetoric consists of elocutio and actio only. ${ }^{29}$

${ }^{27}$ Organum dialecticum et rhetoricum, pp. 180-81.

${ }^{28} \mathrm{~J}$. L. Vives, Rhetorica siue de recte dicendi ratione libri tres.

${ }^{29}$ Organum dialecticum et rhetoricum, pp. 182-85, and P. Ramus, Rhetoricae distinctiones in Quintilianum, pp. 30-31. Subsequently, Peter Ramus would discuss the same doctrine in Scholae in liberales artes (Basel: Eusebius Episcopius et Nicolai fratres haeredes, 1569). 
As mentioned earlier, El Brocense asserts that rhetorical precepts had not yet been correctly classified. However, the categories he proposes indicate that, although he does not mention it, he has, in effect, adopted the position Peter Ramus had proposed a few years earlier. But while following the ideas of Ramus, El Brocense develops them in his own way.

In one sense, El Brocense is opposed to Cicero's attempt to distinguish rhetorical inventio and dispositio from the devices of logic based on the fact that the latter only lends credibility, while the orator also intends to move his audience. El Brocense maintains that inventio and dispositio are one and relevant to all forms of knowledge. In his opinion, inventio and dispositio are part of dialectic in every case in the same way that the spelling of a word does not vary and is always the same in every type of writing regardless of genre. In order for the orator to move the listener he must resort to dialectical devices. ${ }^{30}$

El Brocense admits that, in practice, the different arts inevitably come together, but he believes that the exposition or teaching of the precepts which govern them should be clear and straightforward to avoid confusion. He proposes the following analogy to explain the differences among the various disciplines: the tasks of the worker, the craftsman, and the architect are all necessary to build a house, but this does not mean that these constitute any one discipline or that they are all parts of the same discipline. He proposes that orators and rhetoricians have discussed inventio and dispositio so extensively because the precepts of dialectic had not yet been derived when public speaking began, and that they have invaded a foreign camp which they have held inappropriately until now. ${ }^{31}$

For El Brocense the true difference between dialectic and rhetoric lies in the ultimate objectives of each. He holds that the purpose of dialectic is the use of reason, while rhetoric is concerned with the adornment of speech through eloquence. ${ }^{32}$ In defining these disciplines, $\mathrm{El}$ Brocense does not include persuasion as one of the aims, although it is essential in classical rhetoric. Without persuasion as such, rhetoric is reduced to a simple study

${ }^{30}$ Organum dialecticum et rhetoricum, pp. 184-85.

${ }^{31}$ Ibid., pp. 186-87.

${ }^{32}$ Ibid., pp. 186-89. 
of verbal ornamentation and loses the interdisciplinary nature which had characterized it from the beginning. Rhetoric now undergoes an intensive process of "literaturization" and is ultimately reduced to a discipline of mere ornamental character. By assigning inventio and dispositio to dialectic, El Brocense, along with many other humanists, confuses demonstration with argumentation. This further reduces the realm of rhetoric, since dialectic can be useful in the field of demonstration, but cannot account for argumentation of what is debatable, an essential characteristic of rhetorical discourse.

Although inventio and dispositio are assigned to dialectic, this does not mean they are neglected. On the contrary, in Organum dialecticum et rhetoricum, El Brocense is particularly concerned with reassessing the role of inventio and dispositio, while elocutio is presented according to the model set by Omer Talon.

Despite the change in the parts of discourse assigned to rhetoric or dialectic, the aim of both treatises is to aid in the interpretation of orators and poets. Like the first book of De arte dicendi, the first book of Organum dialecticum et rhetoricum is dedicated to inventio. Relying on Cicero's Topica, El Brocense works out a list of loci where one can find ideas. In De arte dicendi, the topics presented are concerned with either persons or their actions. Upon reviewing the list of arguments related to persons, El Brocense provides examples from speeches as well as works of literature to illustrate the different elements. El Brocense borrows examples from Cicero on the importance of the speaker's nation, but also resorts to Horace, Vergil, and Terence to show the way these authors describe the family, gender, name, age, interests, or death of their characters. ${ }^{33}$ Altogether, there are more examples from poets than orators in the section on topics concerned with persons, illustrating $\mathrm{El}$ Brocense's belief that the elements of inventio are clearly useful in the analysis and composition of literary works.

Literary authors could also find topics concerned with the actions performed by the characters, topics which consider place, manner, time, and cause. By citing examples from poetry, $\mathrm{El}$ Brocense clearly shows how these topics can provide arguments that move the audience when employed in either rhetorical or poetic

${ }^{33}$ De arte dicendi, pp. 42-29. 
discourse. ${ }^{34}$ The section on inventio in De arte dicendi provides a list of elements which lend verisimilitude to the portrayal of human beings, their feelings, their passions, and their actions. This repertoire could be especially useful in the composition and analysis of literary texts, as literature is ultimately based on the artistic representation of character, experience, and human feelings.

Assigning inventio to dialectic in Organum dialecticum et rhetoricum involves a restructuring of this section, although the new logical precepts proposed are also exemplified with quotations from poets. In this way, $\mathrm{El} \mathrm{Brocense}$ presents his own version of the Aristotelian system of causality, which includes final, formal, efficient, and material causes. The final cause, which is the noblest of all, is that for the sake of which something is done or made. El Brocense points out that all philosophical disputes revolve around this most noble of causes, for if we are able to determine its ultimate purpose, the question is resolved. Since the final cause is so important, it is not surprising that the arguments are drawn from Cicero's writings as well as those of Horace and Vergil. ${ }^{35}$

The other causes are also discussed. The formal cause defines what each thing is and what distinguishes it from everything else. In this way, Cicero praises man for his formal cause, since man is endowed with reason, but buildings are also praised or criticized for their form, as in Vergil, and it is possible to persuade by resorting to the form of a house, a ship, or a place. In this way, $E l$ Brocense directly relates the formal cause to description in literary works. The efficient cause is the reason why things exist and is exemplified by quotations from Horace, Petronius, and Martial. The material cause refers to the matter or material from which a thing is made, as exemplified by citations from Ovid or Vergil on the material of palaces and ships. ${ }^{36}$

The chapter dedicated to causes is essential, since accurate knowledge of human affairs is based on them. The many references drawn from literature suggest that literature can employ each and every one of these devices. This requires an effort on our part to understand the conceptual framework of the time.

${ }^{34}$ Ibid., pp. 48-55.

${ }^{35}$ Organum dialecticum et rhetoricum, pp. 196-99.

36Ibid., pp. 198-219. 
Regardless of how strange it many seem to us that classicizing authors would take into account dialectical precepts when composing literary works, this association was a natural one given the framework of Spanish humanism. In fact, at a time when the different disciplines were closely related as parts of an encyclopedic knowledge, $\mathrm{El}$ Brocense had no difficulty resorting to dialectical precepts for the interpretation of poets. The relationship between the rules of dialectic and those that govern poetry clearly reflects the status of literature which, at this time, was in no way an independent form and could, therefore, draw from the different disciplines in order to represent knowledge artistically.

Both the second book of De arte dicendi and that of Organum dialecticum et rhetoricum are dedicated to dispositio. ${ }^{37}$ As indicated earlier, dispositio is divided into two parts: argumentatio and methodus. Argumentation corresponds to the arrangement of a single argument and is concerned with the process of syllogistic reasoning. Method involves arranging the various arguments that make up an oration: exordium, narratio, argumentatio, and peroratio. The discussion of dispositio is essentially the same in both works. However, dispositio belongs to one aspect of rhetoric in De arte dicendi, but is considered a component of dialectic in Organum dialecticum et rhetoricum. Consequently, this requires reformulating sections and introducing logical propositions to account for the redistribution of categories, with the greatest changes to be found in the section on syllogisms.

In fact, the chapter on syllogisms is one of the most interesting parts of the treatise. ${ }^{38}$ According to El Brocense, poets and orators use syllogisms to compose their works, and if this is not obvious at first, it is because artistic expression tends to disguise them. The highest art forms conceal artifice, and it is up to the critic to unveil it. Often, some syllogistic premise is overlooked, implied, or moved to make the exposition or plot more pleasing. ${ }^{39}$ El Brocense makes a point of offering numerous examples which illustrate the

${ }^{37}$ De arte dicendi, pp. 80-101.

${ }^{38}$ Organum dialecticum et rhetoricum, pp. 280-313.

${ }^{39} \mathrm{Ibid}$., pp. 290-97. By pointing out the syllogisms on which literary expressions are based, El Brocense applies the analytical approach proposed by Agricola and imitated by Melanchthon and Ramus in his commentaries on Cicero's speeches. See K. Meerhoff, Rhétorique et poétique au XVI' s. en France, and idem, "Melanchthon lecteur d'Agricola. Rhétorique et analyse textuelle." 
incidence of syllogisms in poetic texts, such as in the following verses from Terence:

Here, quae res in se neque consilium neque modum habet ullum, eam consilio regere non potes.

In amore haec omnia insunt uitia: iniuriae, suspiciones, inimicitiae, indutiae,

bellum, pax rursum; incerta haec si postules ratione certa facere, nihilo plus agas,

quam si des operam, ut cum ratione insanias.

(Sir, something which in and of itself has no reason or moderation cannot be ruled by reason.

There are many obstacles in love: offenses of all kinds, misgivings, hostility, a truce is called, then war, and once again peace. If one attempts to regulate these irregularities with reason, no more is accomplished than if one strives to rant and rave reasonably. $)^{40}$

El Brocense explains the hidden syllogism this way:

Nulla res consilio modoque destituta consilio regi potest;

Omnis amor est consilio modoque destitutus,

Nullus igitur amor consilio regi potest.

(That which lacks reason and knows no moderation, cannot be ruled by [reason];

Love lacks reason and knows no moderation;

Therefore, love cannot be ruled by reason. ${ }^{41}$

For another example El Brocense cites Ovid:

Prospera lux oritur, linguisque animisque fauete:

Nunc dicenda bono sunt bona uerba die.

(A fair light appears, avoid words and thoughts of ill omen:

Fair words are to be uttered on a fair day. $)^{42}$

${ }^{40}$ Terence, Eun. 57-63, cited in Organum dialecticum et rhetoricum, p. 290. Translations in this article are by the author.

${ }^{41}$ Organum dialecticum et rhetoricum, p. 290.

${ }^{42}$ Ovid, Fast. I.71-72, cited in Organum dialecticum et rhetoricum, p. 296. 
According to $\mathrm{El}$ Brocense the verses are based on the following syllogism:

Bono die bona uerba sunt dicenda;

Nunc prosper dies oritur,

Nunc igitur bona uerba sunt dicenda.

(Fair words are to be uttered on a fair day;

A fair day is at hand,

Therefore fair words are to be uttered. $)^{43}$

Syllogisms can also be used ironically, as Ovid does in the following verses:

Fallere credentem nos est operosa puellam

Gloria; simplicitas digna favore fuit.

Sum decepta tuis et amans et femina uerbis.

Dii faciant laudis summa sit ista tuae.

(To deceive a naive maiden is not a difficult

feat; my simplicity was worthy of reward.

I have been seduced by your words as a lover and as a woman.

May the gods grant that your victory be the object of praise. $)^{44}$

El Brocense identifies the following syllogism:

Nullus amantis feminae deceptor est laudandus;

Demophoon est Phyllidis amantis deceptor,

Demophoon igitur non est laudandus.

(He who deceives a woman in love is not to be praised;

Demofonte deceived his lover Filis,

Therefore Demofonte is not to be praised. $)^{45}$

A long list of similar examples follows. El Brocense demonstrates the influence of the teachings of the different disciplines on classical authors, who often, whether consciously or not, resorted

${ }^{43}$ Organum dialecticum et rhetoricum, p. 296.

${ }^{44}$ Ovid, Epist. II.63-66, cited in Organum dialecticum et rhetoricum, p. 296.

${ }^{45}$ Organum dialecticum et rhetoricum, p. 260. 
to syllogisms drawn from rhetoric or dialectic. In this case, $E l$ Brocense's remarkable analysis leaves no doubt about the influence of these disciplines on literary creativity. El Brocense is adamant: he maintains that he has amply demonstrated that poetic expression employs syllogisms. Since his main objective is to provide a means for interpreting Latin authors, his examples are drawn from classical texts. His precepts, however, were still valid in an age of classicism intent on the exaltation of antiquity, and they proved useful for the interpretation of contemporary works as well.

Once the contents of argumentation are presented, El Brocense turns to the parts of discourse: exordium, narratio, argumentatio, and peroratio. ${ }^{46}$ Here, we also see the close relationship between rhetoric and literature. For instance, El Brocense offers a series of guidelines regarding the exordium of judicial oratory, but does not hesitate to exemplify them with a citation from Book IV of Vergil's Georgics, where the author is able to attract the attention of the patron by introducing the theme of beekeeping. ${ }^{47}$ Once again, purely rhetorical precepts are employed to explain literary texts, the exordium of which may be similar to that of speeches. Consequently, the chapter on dispositio clearly shows the relationship between literature and the precepts drawn from the different disciplines.

Finally, the chapter on elocutio is essentially identical in both $D e$ arte dicendi and Organum dialecticum et rhetoricum. ${ }^{48}$ El Brocense is less concerned with this area and admits he follows the model set by

46Ibid., pp. 314-23.

47 Ibid., pp. 317-26.

${ }^{48}$ De arte dicendi, pp. 102-51, and Organum dialecticum et rhetoricum, pp. 326-71. El Brocense excludes some of the traditional figurae in verbis coniunctis from rhetoric and assigns them instead to grammar; these are examined in his grammatical text Minerva. For El Brocense the sentence is the only basic unit of grammar. For this reason in Minerva he only concerns himself with figures of construction (ellipsis, zeugma, pleonasmus, syllepsis, and hyperbaton) which alter the logical grammatical structure of the sentence (Minerva, IV). Normal usage produces habitual breaks with syntactic norms, and this can be manipulated in the interest of rhetoric. On the close relationship between grammar and rhetoric in Minerva, see J. M. Hernándes Terrés, "La herencia de la retórica clásica en la Minerva," Historiographia linguistica 12,3 (1985): 373-87. On Minerva and El Brocense's theory of ellipsis, see mainly C. García, Contribución a la historia de los conceptos gramaticales. La aportación del Brocense (Madrid: C.S.I.C., 1960); F. Salinero, Actualidad lingürstica de Francisco Sánchez de las Brozas (Badajoz: Diputación Provincial, 1973); F. Rivera Cárdena, La Minerva de Francisco Sánchez de las Brozas (Córdoba: Universidad de Córdoba, 1981); S. Arduini, "La teoria dell'ellissi in Francisco Sánchez de las Brozas: una anticipazione della 
Omer Talon. ${ }^{49}$ It seems that his main objective is to show the validity of the precepts of inventio and dispositio in literary interpretation, and he pays less attention to elocutio, as its utility in literature is not questioned. Nonetheless, El Brocense provides numerous examples from poetic texts to exemplify the tropes and figures presented.

The detailed examples of the rules of inventio and dispositio provided by Francisco Sánchez show that the majority of these rules could be applied to the composition of literary texts. However, one must not lose sight of $\mathrm{El}$ Brocense's true objective, which was to propose a systematic set of rules to be applied to the interpretation of the works of orators and poets, which for him meant writers of any literary genre. In his opinion, straightforward adherence to rhetorical rules is all that is required in order to compose good works, but the analysis of these works requires a greater degree of knowledge and skill. El Brocense therefore values the interpretation of literary texts over their composition. This is an original stance vis-à-vis the majority of the authors of the Renaissance, typical of whom was Ramus, who held composition to be as important as analysis.

Thus we have seen that El Brocense's treatises do not simply reflect the process of the "literaturization" of rhetoric implied by reducing rhetoric to elocutio. On the contrary, El Brocense's great contribution is highlighting the relationship between literature and the parts of discourse that had traditionally been least associated with it, which he does not only in his study of elocutio, but also in his analysis of the rules of inventio and dispositio. El Brocense reflects some of the attitudes of his age toward the relationship between dialectic and literature, but also attempts to give a detailed explanation of the nature of this relationship. For this reason, $\mathrm{El}$ Brocense is able to demonstrate conclusively the relevance of the rules of rhetoric and dialectic to the study of literature. In this way, he achieves his aim: to facilitate the interpretation of the poets through the precepts of these disciplines, so that his own work is a clear example of the influence of rhetoric and dialectic on literary criticism in the age of classicism.

grammatica generativa?" Lingua e stile 17 (1982): 341-70; M. Breva Claramonte, Sanctius' Theory of Language. A Contribution to the History of Renaissance Linguistics (Amsterdam: Benjamins, 1982); and the introduction to the French translation of Minerve, trans. and ed. G. Clérico (Lille: Presses Universitaires de Lille, 1982).

49. De arte dicendi, pp. 38-39. 